\title{
Submission Guidelines
}

Submitted papers must not be under consideration by any other journal. Any form of annotation and referencing may be used for the original submission, but accepted papers must be revised to conform to Utilitas house style. A copy of the style sheet is available from the Editor on request. Authors are responsible for observing the laws of copyright when quoting or reproduc-ingmaterial, and for any reproduction fees involved. Authors submitting a paper do so on the understanding that, if accepted for publication, exclusive copyright in the paper shall be assigned to the publishers. In consideration for assignment of copyright, the publisher will supply the author with a pdf of their article. Notwithstanding the assignment of copyright in their contribution, all contributors retain certain non-transferable rights, provided appropriate acknowledgement is made to Utilitas as the original place of publication. You will receive the Assignment of Copyright form for signature on acceptance of your paper.

All submissions, including book reviews, must be made through the Manuscript Central site: http://mc.manuscriptcentral.com/uti

\section{Subscriptions}

Utilitas (ISSN 0953-8208) is published four times a year in March, June, September and December. Four parts form a volume. The 202I subscription price (excluding VAT) of a volume, which includes print and electronic access, is $£_{340}$ (US \$6II in USA, Canada and Mexico). The electronic-only price available to institutional subscribers is $£ 295$ (US \$535 in USA, Canada and Mexico). The printonly price available to institutional subscribers is $£_{345}$ (US $\$ 624$ in USA, Canada and Mexico). Single parts are $£ 99$ (US \$180 in USA, Canada and Mexico) plus postage. EU subscribers (outside the UK) who are not registered for VAT should add VAT at their country's rate. VAT-registered members should provide their VAT registration number. Japanese prices for institutions (including ASP delivery) are available from Kinokuniya Company Ltd, P.O. Box 55, Chitose, Tokyo I56, Japan. Special rates are available to a number of philosophical societies and associations.

Orders, which must be accompanied by payment, may be sent to a bookseller, subscription agent or direct to the publisher: Cambridge University Press,
Journals Fulfillment Department, UPH, Shaftesbury Road, Cambridge CB2 8BS, UK; or in the USA, Canada and Mexico: Cambridge University Press, Journals Fulfillment Department, I Liberty Plaza, Floor 20, New York, NY, Iooo6, USA. Periodicals postage is paid at New York, NY and at additional mailing offices.

\section{Copying}

This journal is registered with the Copyright Clearance Center, 222 Rosewood Drive, Danvers, MA or923, USA. Organizations in the USA which are also registered with the C.C.C. may therefore copy material (beyond the limits permitted by sections 107 and I08 of U.S. Copyright law) subject to payment to the C.C.C of the per copy fee of \$30. This consent does not extend to multiple copying for promotional or commercial purposes. Code 0953-8208/I5. ISI Tear Sheet Service, 350I Market Street, Philadelphia, PA I9I04, USA, is authorized to supply single copies of separate articles for private use only. Organizations authorized by the Copyright Licensing Agency may also copy material, subject to the usual conditions. For all other use, permission should be sought from Cambridge or from the American Branch of Cambridge University Press. 


\section{Utilitas}

\section{CONTENTS}

\section{Articles}

Comprehensive or Political Liberalism? The Impartial Spectator

and the Justification of Political Principles Nir BEN-Moshe

Finding Pleasure and Satisfaction in Perfectionism Michael Hayes

270

Bentham's International Political Theory: Taking States'

Responsibilities Seriously BENJAMIN BOURCIER

Equality for Prospective People: A Novel Statement and Defence Alex Voorhoeve

Sufficiency and the Minimally Good Life Nicole Hassoun

Value Conservatism and its Challenge to Consequentialism

REUBEN SASS

Replies

The Demandingness of Individual Climate Duties: A Reply

to Fragnière Colin Hickey

Attitudinal Theories of Pleasure and De Re Desires

ELIZABETH VENTHAM

Book Reviews

Shelly Kagan, How to Count Animals, More or Less ANDRIUS GALIŠANKA

Chris Barker, Educating Liberty: Democracy and Aristocracy in J. S. Mill's Political Thought D. N. BYRNE 